The first total synthesi s of bufobutanoi $c$ acid by two routes based on nucl eophi I ic subst i tuti on reacti on on indol e nucl eus

\begin{tabular}{|l|l|}
\hline 著者 & $\begin{array}{l}\text { Kur auchi Takashi, Nagahama Yoshi yuki, Hasegawa } \\
\text { Nasakazu, Yamada Koj i, Somei Nesanor i }\end{array}$ \\
\hline $\begin{array}{l}\text { j our nal or } \\
\text { publ i cat i on t i t l e }\end{array}$ & Het er ocycl es \\
\hline vol une & 53 \\
\hline number & 5 \\
\hline page r ange & $1017-1019$ \\
\hline year & 2000-05-01 \\
\hline URL & ht t p: //hdl . handl e. net /2297/4358 \\
\hline
\end{tabular}




\title{
THE FIRST TOTAL SYNTHESIS OF BUFOBUTANOIC ACID BY TWO ROUTES BASED ON NUCLEOPHILIC SUBSTITUTION REACTION ON INDOLE NUCLEUS 1
}

\author{
Takashi Kurauchi, Yoshiyuki Nagahama, Masakazu Hasegawa, Koji Yamada, \\ and Masanori Somei* \\ Faculty of Pharmaceutical Sciences, Kanazawa University, \\ 13-1 Takara-machi, Kanazawa 920-0934, Japan
}

\begin{abstract}
Regioselective nucleophilic substitution reaction of 1-hydroxytryptamines led to establish two novel routes for the first synthesis of bufobutanoic acid. An effective synthesis of 5-benzyloxytryptamine from tryptamine is also reported.
\end{abstract}

In 1999, Kamano and co-workers ${ }^{2}$ isolated bufobutanoic acid (1a, Scheme 1$)$ as a cytotoxic substance against murine P388 lymphocytic leukemia cells from $\mathrm{Ch}^{\prime}$ an $\mathrm{Su}$ and determined its structure. From our ongoing project for developing biologically active novel compounds, ${ }^{3}$ we have much interested in $1 \mathrm{a}$ and intended to establish a methodology applicable for producing its various congeners. To meet our end, we initially needed simple synthesis of 1a. Now, we have succeeded in developing two routes based on 1-hydroxyindole chemistry. 4

The first route is the one utilizing 1-hydroxy- $N b$-methoxycarbonyltryptamine (3a) as an intermediate, a potent inhibitor of platelet aggregation. 5 Thus, 3a, obtained in three steps from tryptamine (2) in $62 \%$ overall yield as described before, ${ }^{6}$ was converted to $4 \mathrm{~b}$ in $48 \%$ yield by the regioselective hydroxylation at the 5-position upon the reaction with $85 \% \mathrm{HCOOH}$ at room temperature for $24 \mathrm{~h}$. Interestingly, the corresponding 1-methoxy- $\mathrm{Nb}$-methoxycarbonyltryptamine ${ }^{6}(3 \mathrm{~b})$ provided $4 \mathrm{a}$ selectively in $69 \%$ yield by the similar treatment with $85 \% \mathrm{HCOOH}$ at $80^{\circ} \mathrm{C}$ for $20 \mathrm{~min}$. Subsequent reaction of $4 \mathrm{a}$ with $85 \% \mathrm{HCOOH}$ at room temperature for 2 days provided $\mathbf{4 b}$ in $70 \%$ yield together with $10 \%$ yield of starting material.

The reaction of $4 \mathrm{~b}$ with benzyl bromide in the presence of $\mathrm{K}_{2} \mathrm{CO}_{3}$ in DMF afforded $4 \mathrm{c}$ in $94 \%$ yield. Alkaline hydrolysis of $4 \mathrm{c}$ with $10 \% \mathrm{NaOH}$ in refluxing $\mathrm{MeOH}$ provided $96 \%$ yield of 5-benzyloxytryptamine (5). ${ }^{7}$ With an useful building block for preparing various serotonin derivatives in hand, it was converted to 6 in $96 \%$ yield by the reaction with succinic anhydride in THF. Catalytic hydrogenation of 6 over $10 \% \mathrm{Pd} / \mathrm{C}$ at room temperature produced $1 \mathrm{a}$ in $99 \%$ yield. The spectra of $1 \mathrm{a}$ are identical with those reported in the literature. ${ }^{2}$ Thus, the first synthesis of $1 \mathrm{a}$ was achieved in eight steps from 2 in $25 \%$ overall yield with $33 \%$ originality rate. 8

As the second one, six-steps synthesis of $1 \mathrm{a}$ in $13 \%$ overall yield with $43 \%$ originality rate was developed. Tryptamine (2) was initially reacted with succinic anhydride in THF at room temperature, followed by methylation with $\mathrm{CH}_{2} \mathrm{~N}_{2}$ in one pot procedure to give $\mathrm{Nb}$-methoxysuccinyltryptamine (7) in $89 \%$ yield. Subsequent reduction of 7 with $\mathrm{Et}_{3} \mathrm{SiH}$ in $\mathrm{CF}_{3} \mathrm{COOH}^{9}$ at $60^{\circ} \mathrm{C}$ provided the corresponding 2,3-dihydroindole (8) in $99 \%$ yield. Our 1-hydroxyindole synthetic method using $\mathrm{Na}_{2} \mathrm{WO}_{4} \cdot 2 \mathrm{H}_{2} \mathrm{O}^{4}$ and 


\section{Scheme 1}
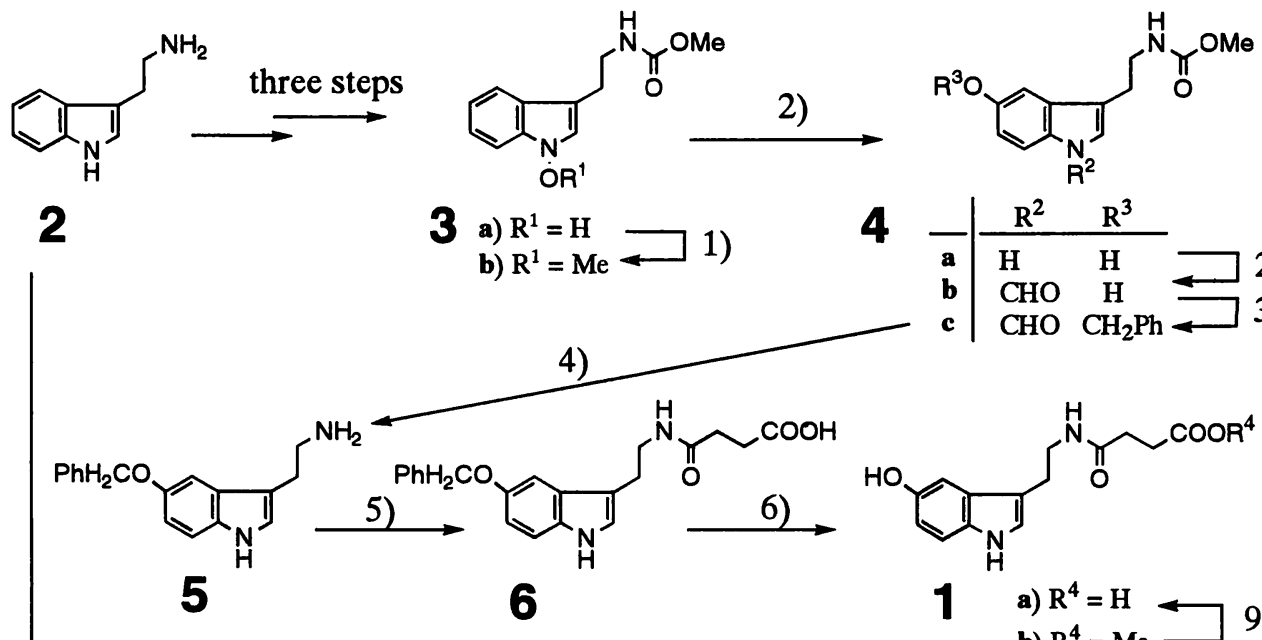

\begin{tabular}{ll|ll}
4 & - & $\mathrm{R}^{2}$ & $\mathrm{R}^{3}$ \\
$\mathbf{a}$ & $\mathrm{H}$ & $\mathrm{H}$ \\
$\mathbf{b}$ & $\mathrm{CHO}$ & $\mathrm{H}$ \\
$\mathbf{c}$ & $\mathrm{CHO}$ & $\mathrm{CH}_{2} \mathrm{Ph}$
\end{tabular}

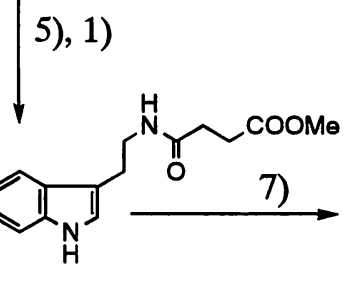

7<smiles></smiles>

8

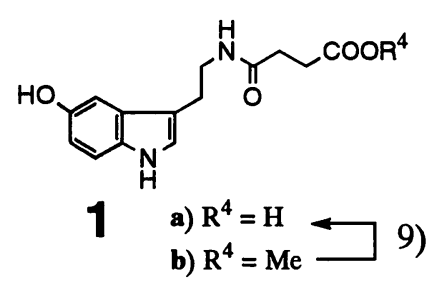

1) $\mathrm{CH}_{2} \mathrm{~N}_{2}$; 2) $85 \% \mathrm{HCOOH}$; 3) $\mathrm{PhCH}_{2} \mathrm{Br}, \mathrm{K}_{2} \mathrm{CO}_{3}, \mathrm{DMF}$; 4) $10 \% \mathrm{NaOH}, \mathrm{MeOH}$; 5) succinic anhydride, THF; 6) $10 \% \mathrm{Pd} / \mathrm{C}, \mathrm{H}_{2}$; 7) $\mathrm{Et}_{3} \mathrm{SiH}, \mathrm{CF}_{3} \mathrm{COOH}$; 8) $\mathrm{Na}_{2} \mathrm{WO}_{4} \cdot 2 \mathrm{H}_{2} \mathrm{O}, 30 \% \mathrm{H}_{2} \mathrm{O}_{2}$; 9) $1_{\mathrm{M}} \mathrm{K}_{2} \mathrm{CO}_{3}$, MeOH.

$30 \% \mathrm{H}_{2} \mathrm{O}_{2}$ at room temperature was successfully applied to 8 giving the desired 1-hydroxytryptamine (9a) in $56 \%$ yield. Structure of $9 \mathrm{a}$ was confirmed by converting it to 1-methoxytryptamine (9b) in $86 \%$ yield by the reaction with $\mathrm{CH}_{2} \mathrm{~N}_{2}$. Then, $9 \mathrm{a}$ was treated with $85 \% \mathrm{HCOOH}$ at $50^{\circ} \mathrm{C}$ for $50 \mathrm{~min}$ to give serotonin derivative (1b) in $38 \%$ yield. Finally, ester part of $1 \mathrm{~b}$ was hydrolyzed with $1_{\mathrm{M}} \mathrm{K}_{2} \mathrm{CO}_{3}$ in $\mathrm{MeOH}$ at $50^{\circ} \mathrm{C}$ to provide $1 \mathrm{a}$ in $70 \%$ yield.

In conclusion, we have disclosed that nucleophilic substitution reaction ${ }^{10}$ of 1-hydroxytryptamines ${ }^{11}$ is a suitable methodology for the preparations of serotonin congeners.

\section{ACKNOWLEDGMENT}

This work is supported in part by a Grant-in-Aid for Scientific Research from the Ministry of Education, Science, Sports, and Culture, Japan, which is gratefully acknowledged.

\section{REFERENCES AND NOTES}

1. This is Part 96 of a series entitled "The Chemistry of Indoles". Part 95: M. Somei, K. Noguchi, R. Yamagami, Y. Kawada, K. Yamada, and F. Yamada, Heterocycles, 2000, 53, 7. All new compounds 
gave satisfactory spectral and elemental analysis or high-resolution MS data for crystals or gums, respectively. 1b, gum; $4 \mathrm{a}$, gum; $\mathbf{4 b}$, gum; $4 \mathbf{c}$, gum; 5 , mp $97.5-99.5^{\circ} \mathrm{C} ; 6, \mathrm{mp} 145-147^{\circ} \mathrm{C} ; 7, \mathrm{mp}$ $118-120^{\circ} \mathrm{C} ; 8, \mathrm{mp} 74-75^{\circ} \mathrm{C} ; 9 \mathrm{a}, \mathrm{mp} 151.5-153.5^{\circ} \mathrm{C}$.

2. Y. Kamano, H. Morita, R. Takano, A. Kotake, T. Nogawa, H. Hashima, K. Takeya, H. Itokawa, and G. R. Pettit, Heterocycles, 1999, 50, 499.

3. K. Nakagawa and M. Somei, Heterocycles, 1991, 32, 873; F. Yamada, K. Kobayashi, A. Shimizu, N. Aoki, and M. Somei, ibid., 1993, 36, 2783; F. Yamada, S. Hamabuchi, A. Shimizu, and M. Somei, ibid., 1995, 41, 1905; M. Somei, Y. Fukui, and M. Hasegawa, ibid., 1995, 41, 2157; M. Somei, H. Hayashi, T. Izumi, and S. Ohmoto, ibid., 1995, 41, 2161; M. Somei, K. Yamada, M. Hasegawa, M. Tabata, Y. Nagahama, H. Morikawa, and F. Yamada, ibid., 1996, 43, 1855; M. Somei, F. Yamada, T. Izumi, and M. Nakajou, ibid., 1997, 45, 2327; F. Yamada, M. Tamura, and M. Somei, ibid., 1998, 49, 451; M. Somei, N. Oshikiri, M. Hasegawa, and F. Yamada, ibid., 1999, 51, 1237. See also reference 11.

4. Review: M. Somei, Heterocycles, 1999, 50, 1157 and references cited therein.

5. M. Somei, K. Yamada, M. Hasegawa, M. Tabata, Y. Nagahama, H. Morikawa, and F. Yamada, Heterocycles, 1996, 43, 1855.

6. M. Somei, K. Kobayashi, K. Tanii, T. Mochizuki, Y. Kawada, and Y. Fukui, Heterocycles, 1995, 40, 119.

7. Although hydrochloride of $\mathbf{5}$ is commercially available from Sigma, it is expensive and therefore not suitable as a common starting material for multi-gram scale production of serotonin congeners. Our present method seems to be better to obtain 5 at cheaper cost compared to the conventional one. Another choice is to utilize serotonin hydrochloride as a starting material.

8. M. Somei, J. Synth. Org. Chem., 1982, 40, 387; M. Somei, Y. Makita, and F. Yamada, The 3rd International Kyoto Conference on New Aspects of Organic Chemistry, Abstracts Papers, Nov., 1985, p. 128; M. Somei, Yakugaku Zasshi, 1988, 108, 361.

Originality rate is the result of the following calculation:

Originality Rate $(\%)=100 \times$ [Number of Newly Developed Steps +1$] \div[$ Total Number of Synthetic Steps + 1]

9. A. E. Lanzilotti, R. Littell, W. J. Fanshawe, T. C. McKenzie, and F. M. Lovell, J. Org. Chem., 1979, 44, 4809.

10. J. A. Joule, "Progress in Heterocyclic Chemistry", Vol. 11, ed. by G. W. Gribble and T. L. Gilchrist, Elsevier Science Ltd., Oxford, 1999, pp. 45-65.

11. M. Somei, H. Morikawa, K. Yamada, and F. Yamada, Heterocycles, 1998, 48, 1117; M. Hasegawa, K. Yamada, Y. Nagahama, and M. Somei, ibid., 1999, 51, 2815. 